\title{
Farmers Community Empowerment through Institutional Strengthening of Rural Food Barn
}

\author{
Mohamad Ikbal Bahua (Corresponding author) \\ Department of Agrotecnology, Faculty of Agriculture, State University of Gorontalo, \\ Gorontalo 96000, Indonesia. \\ Tel: +62-85240795645. E-mail: mohamadikbalbahua@gmail.com
}

\author{
Muhammad Arsyad \\ Department of Agricultural Socio-economics, Faculty of Agriculture, Hasanuddin University, \\ Makassar 90245, South Sulawesi, Indonesia. \\ Tel.+62-411-586014. Fax.+62-411-586014 E-mail: arsyad@unhas.ac.id \\ Muh. Hatta Jamil \\ Department of Agricultural Socio-economics, Faculty of Agriculture, Hasanuddin University, \\ Makassar 90245, South Sulawesi, Indonesia. \\ Tel: +62-85253990215 E-mail: hattaj@yahoo.com
}

(Received: Apr 20, 2015; Reviewed: Aug 14, 2015; Accepted: Nov 15, 2016)

\begin{abstract}
Food insecurity is one of the crucial problems to solve. The research objectives are: (1) to describe the form of community empowerment farmers' through institutional strengthening of rural food barn, (2) to explain the process of community empowerment farmers' through institutional strengthening of rural food barn, and (3) to find out the constraints faced in the empowerment of peasant communities by strengthening institutional of rural food barn. The research was conducted in Huyula Subdistrict Mootilango Gorontalo, Indonesia, employing qualitative methods by selecting farmers who are using barns to store grain as food reserves. Data were collected through in-depth interview to the informant. The results showed that the empowerment of peasant communities by strengthening institutional food barns can be performed well based on the potential and capability of farmers. Thus the policy of strengthening institutional food barns rural effect on the empowerment of peasant communities in improving family welfare. This implies that Indonesian government still needs to strengthen institutional of of rural food barn to keep food security in broad sense.
\end{abstract}

Keywords: Empowerment; strengthening; institutional; barn; food; farmers

\section{Introduction}

Food security are the condition of the food the fulfillment for the community which is seen from food availability, food distribution, food consumption and quality, safe, diverse, nutritious, evenly, affordable and do not conflict with religion, and culture of the people in order to live healthy and productive in a sustainable way.
Development of food security is to meet the needs of basic human that provide benefit fair and even based on self-reliant, and shall not in contrary with confidence the community. Development food security manifest in the various program sourced of the potential of the local community in meet their food needs based on the mechanism food availability, food consumption, and 
food distribution sustainable.

The food availability serves ensure food supply to meet the needs of the entire population, both in terms of the quantity, quality, diversity and security. Distribution subsystem serves embody distribution system efficient to ensure that all households can obtain food in quantity and quality of being ample all the time and affordable. While consumption subsystem serves directing the food to the national quality meet rule, diversity, the nutrition, and its security for the community.

Husodo (2001) explained that priority activities in development food security are empowerment to enable them to help themselves in achieving food security. The community empowerment be done by increasing the capacity of human resources, build community institutions, and providing production facilities (technology and capital) to compete entered in labor market and a trying occasion to create and improve household income.

Sibuea (2009), institutional barns village is a system special norm setting a series of action patterned steady and structured needs food reserve villagers. With regard to the problem of food security forward increasingly complex, whether as a result of global food crisis, the global economic crisis and the impact of global warming, then barns as institutions reserve be supporting food is strategic developed in the region.

The system barns as center reserve food, especially in the rural area, are becoming difficult to find. The local knowledge (indigenous knowledge) eroded by the change of era. There are four the problem system barns village increasingly marginalized: (1) tendency farmers behave consumption, (2) the institutional models other thriving, (3) the farmers entangled futures, and (4) a posture farmers that tends to apathetic in line with loss of values cooperation among the community. Hence, the potential barns this village should be expanded and be revitalized through the process of community empowerment systematically, of an integrated and sustainable by involving all related elements (Hermanto, 2009) There is an indication that cocoa production institution is not working well as farmers' expectations (Nuddin et al., 2015).

The research objectives are: (1) to describe the form of community empowerment farmers' through institutional strengthening of rural food barn, (2) to explain the process of community empowerment farmers' through institutional strengthening of rural food barn, and (3) to find out the constraints faced in the empowerment of peasant communities by strengthening institutional of rural food barn.

\section{Materials and Method}

\subsection{Design Research}

This research in design with the qualitative method, in research social science fundamentally the qualitative method very relying on observation man in own region and is associated with the men in language and itself. In this research, researchers collect some information deeply about the form of, the process and obstacles empowerment of communities through institutional strengthening of rural food barns. 


\subsection{Research Site}

This research was carried out in Huyula Village, Subdistrict Mootilango Gorontalo Regency, Indonesia from July until September 2015. Choice of location for the was done intentionally (purposive) because in the qualitative study researchers has a lot of spend their spare time in the field, hence ease in do research is needed. Based on it Villages Huyula, because in this village broad paddy fields reached 51.3 hectare and there are community members farmers to use barns village as a place for storing a reserve grain who they built around location paddy fields.

\subsection{Data Sources}

Data sources used in this research is: Informants. The determination of informants was conducted using technique snowball, it means after entering research locations, researchers call some informants appointed to ask for information. A lot of issues of events that pertaining to the matter and the focus of research, among other: the form of empowerment, empowerment processes, the obstacles in the empowerment of communities through institutional strengthening of rural food barns. Some documents used relating to the substance research obtained from government agencies, like department of agriculture and food security, cooperative agencies, trade and industry, the executive body counseling, social services agency and transmigration, sub district office.

\subsection{Analysis Method}

Data analysis used in the research was descriptive analysis qualitative with reference to data analysis the results of inter- views in depth with farmers as informants. Interviews are presented in the table and interpreting answers or statement farmers into form of sentence descriptive leading at issue research.

\section{Results and Discussion}

\subsection{The Community Empowerment Through} Strengthening Farm Barns Village

Community empowerment in the context of food security is the provision of strength and responsibility to the community to maintain the availability of food, food consumption, and food distribution through institutional barns. The community empowerment through strengthening of rural farm barn is displayed in Table 1.

Table 1. The form of community empowerment of farmers through institutional strengthening barns village

\begin{tabular}{|c|c|c|}
\hline No & $\begin{array}{c}\text { Empowerment } \\
\text { Pattern }\end{array}$ & $\begin{array}{c}\text { Empowerment } \\
\text { Dimensions }\end{array}$ \\
\hline 1 & $\begin{array}{l}\text { Capacity building } \\
\text { human resources }\end{array}$ & $\begin{array}{l}\text { - Improved knowledge and skill } \\
\text { management barns village } \\
\text { - Increase the participation farmers } \\
\text { - Motivate farmers in managing } \\
\text { barns }\end{array}$ \\
\hline 2 & $\begin{array}{l}\text { Capital } \\
\text { strengthening } \\
\text { farming }\end{array}$ & $\begin{array}{l}\text { - Gives means of agricultural } \\
\text { production } \\
\text { - Developing joint business group }\end{array}$ \\
\hline 3 & $\begin{array}{l}\text { System } \\
\text { development } \\
\text { resinous warehouse }\end{array}$ & $\begin{array}{l}\text { - Strengthening management post } \\
\text { harvest } \\
\text { - The development of diversification } \\
\text { food }\end{array}$ \\
\hline
\end{tabular}

Table 1 clearly shows that the form of community empowerment of farmers through institutional strengthening barns village, for example through capacity building human resources, strengthening capital farming, and development system resinous warehouse.

Community development by increasing the capacity of human resources carried by means of: (1) improve knowledge and skills management barns village through a system extension and socialization to farmers about 
uses, function and orders of institutional barns village in managing agricultural production to support food security program in rural areas, (2) increase participation farmers, empowerment processes done through increased cooperation between farmers, the government and private sectors in support food security program in rural area, (3) motivate farmers manage barns are held by increasing the spirit of farmers in using barns villages as one of the handling of food availability in rural areas. Motivation it will be confidence, the ability affiliated and the ability high performing well in improve the availability of food in rural area.

Community empowerment in terms of capital strengthening farming enterprises be implemented through effort: (1) granting aid means of production, empowerment processes is conducted by providing aid seed, fertilizer, and pesticide and costs of land management in the implementation of the cultivation of paddy rice field, so as to strengthen institutional barns village, and (2) The development of joint business group. Empowerment done by helping farmers which lack of capital farming enterprises with granting business capital rolling so that farmers can manage farming enterprises together to develop institutional barns village, so that food security in rural areas can be achieved.

System development resinous warehouse is a form of community empowerment developed to strengthen position farmers in terms of strengthening management after harvest. The form of community empowerment this directed to raise to a position farmers in managing institutional barns on their crops before is sold as the market price.

\subsection{Farmers Community Empowerment} through Strengthening Institutional of Rural Farm Barn

Strengthening rural food barns were implemented through the process of community development, consisting of: created social conditions conducive, strengthen economic potential, and protect people from his own weaknesses. The process of community empowerment by creating social situation conducive to institutional barns village that allows potential the community to developing (enabling). The process through a meeting in formulating rights and obligations society by farming potential for the barns, strengthening the capacity of institutional through increasing the knowledge and skill in managing assets institutional, and motivate the community to use barns in the face of fluctuations the price of rice.

The results of the research in accordance with statements from Maslow (1956) stated that, each individual motivated by means of needs that being innate since born and make the individuals the been satisfied with their needs, so that it can be survive. Mcclelland (1961) explained that individual would develop its potential through been the motivation to excel achievement motivation associated with three needs, namely: (1) need for achievement ( $n$-ach), (2) need for power (n-power) and (3) needs affiliated ( $n$ aff).

Strengthen community economic potential is empowerment processes that deals with input supply to strengthen farmers in developing institutional of rural food barn (Table 2). As clearly shown in Table 2, the process the empowerment of communities 
Table 2. Empowerment Processes the Community through Institutional Strengthening Barns Village

\begin{tabular}{|c|c|c|}
\hline No & $\begin{array}{c}\text { Community } \\
\text { Empowerment Process }\end{array}$ & $\begin{array}{l}\text { Empowerment } \\
\text { Dimensions }\end{array}$ \\
\hline 1 & $\begin{array}{l}\text { Created social situation } \\
\text { conducive institutional barns } \\
\text { village }\end{array}$ & $\begin{array}{l}\text { - Deliberation to formulate rights and obligations society by } \\
\text { farming potential for the barns. } \\
\text { - Strengthening institutional capacity in advance their } \\
\text { knowledge and skill managing assets institutional. } \\
\text { - Motivate of people use barns in the face of fluctuations the } \\
\text { price of rice. }\end{array}$ \\
\hline 2 & $\begin{array}{l}\text { Strengthen community eco- } \\
\text { nomic potential on institu- } \\
\text { tional affairs barns village }\end{array}$ & $\begin{array}{l}\text { - Give market information being up to date and sustainable. } \\
\text { - Ensuring the sustainability of rice production through the } \\
\text { provision of agricultural production facilities. } \\
\text { - Building roads access of farming business. } \\
\text { - Diversified food in accordance potential local. }\end{array}$ \\
\hline 3 & $\begin{array}{l}\text { Protect the people from his } \\
\text { own weaknesses }\end{array}$ & $\begin{array}{l}\text { - Impose regulations the basic price of the purchase of grain } \\
\text { by the government. } \\
\text { - Establish cooperation with the government to ensure the } \\
\text { purchase of rice from the community. } \\
\text { - Trying to establish stratification marketing rice at regional } \\
\text { level, national, and international. }\end{array}$ \\
\hline
\end{tabular}

through institutional strengthening barns villages was carried out through effort: (1) create social situations conducive for institutional barns village, (2) strengthening the community economic potential on institutional barns village, and (3) protect the people from his own weaknesses.

The process of community empowerment by creating social situation conducive to institutional barns village allow potential the community to developing (enabling). This process was done through a meeting in formulating rights and obligations society by potential farming in the region barns. Strengthening the capacity of institutional through increasing the knowledge and skill in managing assets institutional. Motivate people use barns in the face of fluctuations in the price of rice.

The result of the research in accordance with statements from Maslow (1956) stated that, each individual motivated by means of needs that being innate since born and make the individuals the been satisfied with their needs, so that it can be survive. Mcclelland (1961) explained that those individuals will develop the potential through the motivation to excel (achievement motivation) related to three needs, namely: (1) the need for achievement (need of achievement) n-ach, (2) the need for power (need of power) n-power and (3) needs affiliated (need of affiliation) n-aff.

Strengthen community economic potential is empowerment processes that deals with the provision of input to strengthen the position of farmers in developing institutional barns village. Empowerment processes this is done through strengthening provision of access to market information so that farmers to know the development of the price of rice at each harvest, so they do not caught in futures to developing in rural areas. According to Cardy, et al (1995) and Beckert (2005) strengthening the potential the community through empowerment processes is building roads access farming, so that farmers they had experienced no difficulty in achieving 
complex farming and the process of markets for produce farming. The results of the study Bryan and Glenn (2004) concluded that infrastructure development and means of basic as: the path, irrigation, electricity, school, and others is the most important to strengthen the potential the community as business open access and retardation the people of a areas.

Empowerment processes the community through institutional strengthening barns villages was carried out with to protect the people from his own weaknesses. The process of community empowerment this is done through the determination of the basic price of the purchase of grain by the government. The determination of the basic price of necessary to protect produce farmers from fluctuations the price of rice. The research results Sudaryanto, et al (2005) concluded that the government provide protection to farmers through rules area or governor decree/ regent/mayor about basic pricing purchases of rice in the countryside as business institutional strengthening barns village in support of food security program.

\subsection{Constraints in Community Empower-} ment and Institutional Strengthening of

\section{Rural Food Barn}

There are two constraints will be explained in this session as clearly shown in Table 3. Obstacles internal causing the management of and motivation farmers to strengthen institutional barns village be diminished. Institutional management barns need human resources having competence management farming and require a budget large enough to safeguard crop charity farmer in barns. This is in accordance with the opinions Swasono (2003) who explained that the potential resource and the provision of budget had an influence on the process of institutional revitalization rural barn. To prevent obstacles, then required a training program management organization for farmers and provision of the budget at every year through the office of relevant agencies, because of that rural barn is able to survive in accordance with era development.

Table 3. The Internal and External in the Empowerment of Communities through Strengthening Barns Village.

\begin{tabular}{ccc}
\hline No & $\begin{array}{c}\text { Obstacles Community } \\
\text { Empowerment }\end{array}$ & $\begin{array}{c}\text { Obstacles Community } \\
\text { Empowerment }\end{array}$ \\
\hline 1 & Obstacles internal & $\begin{array}{l}- \text { The limited human resources } \\
- \\
\text { The limited budget for the } \\
\text { development of barns village }\end{array}$ \\
\hline 2 & Obstacles external & $\begin{array}{l}\text { Partnership farmers and the } \\
\text { government yet interwoven }\end{array}$ \\
\hline
\end{tabular}

External obstacles in the process empowerment of communities through institutional strengthening of rural barn village, there is no intervention partnership of the government. According to Yustika (2007), a partnership system on the policy food security program directed to the process the availability of distribution and food consumption are carried between the government with farmers as producer. Pattern the partnership is symbiotic mutualism impact better for the development program of food security and institution strengthening of rural barns.

\section{Conclusion}

It can be concluded that: (1) the form of empowerment of communities through institutional strengthening of rural food barns: improving the capacity of human resources, capital strengthening farming, system devel- 
opment and resinous warehouse, (2) the process empowerment of communities through institutional strengthening barns in the village: create the circumstances or climate social; strengthen potential or the power held by the farm, and to protect the people from all his own weaknesses, (3) constraints faced in empowerment of communities through institutional strengthening of rural barns, namely: obstacles internally (limited human resources especially farmers and the limited allocated budget has at the farm gate in developing barns village). Meanwhile, external obstacles are partnership of government to ensure the price of rice.

\section{References}

Bryan DT, Glenn DI. (2004). "Agent Performance dan Customer Satisfaction." Jurnal of Extension. Number 6 Volume 42 Desember 2004.

Beckert TE. (2005). "Fostering Autonomy In Adolescents: A Model of Cognitive Autonomy and Self Evaluation.” Journal Fostering. Number 20 Volume 3.

Cardy, Robert L, Dobbins, Gregory H, Carson, Kenneth P. (1995). TQM and HRM: "Improving Performance Appraisal Research, Theory, and Practice." Revue Canadienne des Sciences de l'Administration. Montreal, 12(2).

Hendriyati, Suradi, Sugiyanto. (2005). Pengembangan Model Pemberdayaan Komunitas Adat Terpencil. Pusat Penelitian dan Pengembangan Usaha Kesejahteraan Sosial. Badan Pelatihan dan Pengembangan Sosial. Departemen Sosial RI. Jakarta (in Indonesian).

Hermanto. (2009). Revitalisasi Lembaga
Lumbung Pangan. Bangka Pos edisi: 14 Maret 2009. (in Indonesian)

Maslow A. (1956). Maslow's Hierarchy of Needs motivational model. http://businessballs.com/maslow.htm [12 April 2016].

McClelland CD. (1961). David C Mcclelland's Motivational Needs Theory. http://businessballs.com/davidmcclelland.htm [12 April 2016].

Nuddin, A., S. Yusuf, N., M. Viantika, Sulianderi, (2015). An Alternative Model of Cocoa Production Institution: A Solution in Facing Asean Economic Community. International Journal of Agriculture System, 3(2):43-56.

Sibuea P. (2009). The Revitalization of the Role of Barn Village to Take care of Food Insecurity. "The Journal Results" Department of Technology Agricultural Produce. Khatolik University of Santo Thomas North Sumatera Medan.

Siswono Yudo Husodo. (2001). Kemandirian di Bidang Pangan, Kebutuhan Negara Kita. Paper at Seminar Nasional Teknologi Pangan, Semarang, 9-10 Oktober 2001 (in Indonesian).

Sudaryanto T, Simatupang P, Kariyasa K. (2005). "Konsep Sistem Usaha Pertanian Serta Peranan BPTP dalam Rekayasa Teknologi Pertanian Spesifik Lokasi." Jurnal Analisis Kebijakan Pertanian. 3(3). 349-366 (in Indonesian).

Swasono SE. (2003). "Kemandirian Ekonomi: Menghapus Sistem Ekonomi Subordinasi Membangun Ekonomi Rakyat." Jurnal Ekonomi Rakyat (in Indonesian). 